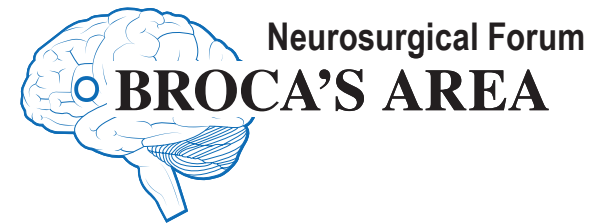

\section{Brief encounters that last a lifetime: an immigrant neurosurgeon's reflections on American exceptionalism, George Floyd, sunlight, and race}

\author{
Jacques J. Morcos, MD, FRCS(Eng), FRCS(Ed) \\ Department of Neurological Surgery, University of Miami, Florida
}

History, despite its wrenching pain, cannot be unlived, but if faced with courage, need not be lived again.

$$
\text { - Maya Angelou }
$$

\section{Miami, June 6, 2020}

This amazing country we live in is a very special place indeed. It has celebrated the best of times and anguished through the worst of times. Today's social unrest sweeping the nation, on the tail of a global pandemic, will not go down in history as one of our finest hours, unless all the channeled anger, frustration, and loss of life inspire and produce meaningful social reform. Yet true reforms will not come to pass unless prejudice and racism are crushed from within, one person at a time, elevating us, the people, to a better place. It is out of civic duty and moral imperative that we must transcend ourselves in these solemn times. To the extent that each one of us loves our fellow men and women, and with the premise that each of us is equipped with a unique set of gifts, skills, tools, and influences, inborn and acquired, we must reach deep within, perhaps beyond the limit and comfort of our own sensibilities and those of the people around us. We must will the change with all our might before engaging in constructive education and reform. It behooves us today to make 2020 our finest hour since the civil rights movement of more than half a century ago. This requires collective introspection.

As an immigrant who felt welcomed to this country, I myself begin this personal exploratory journey, an exercise I hope all of us are engaging in. I first need to muster all the positive inner energy I can for this reflective voyage. There is no better way to accomplish this than for me to rekindle the past, crystallize my thoughts and feelings about this land and her people, and rediscover how I came to fall in love with both.

\section{Beirut, October 23, 1983}

Early on a Sunday morning, October 23, 1983, a formidable explosion perpetrated by a suicide bomber took the lives of 241 Americans. Among the dead were 220 Marines, 18 Navy sailors, and 3 Army soldiers, in addition to more than 100 injured. The scene of this horrific act-the worst single-day death toll for Marines since the Battle of Iwo Jima-was a nondescript four-story aviation administration building next to the airport in Beirut, Lebanon. It was the headquarters of the US 1st Battalion, 8th Marine Regiment, a peacekeeping force dispatched by President Reagan in an attempt to temper the horrors of the Lebanese Civil War, which had been raging since 1975 and would not officially end until 1990.

Most of the casualties of that infamous day were rushed to the American University of Beirut Medical Center (AUBMC). That emergency room (ER) was not foreign to mass casualties. Its staff had witnessed unspeakable violence and mayhem, with hordes of dismembered bodies of civilians and militia fighters from all nationalities, factions, parties, and religions raining in on a daily basis since 1975. But on that fateful Sunday, the sheer scope of the horror was simply overwhelming, even to the experienced physicians and nurses. Bodies of the injured and dead spilled outside the small ER and were laid down in endless rows on the pavements and streets around the hospital. Every available physician, surgeon, resident, medical student, and nurse came to help triage the injured.

I grew up in Lebanon and lived there for most of the war. I was a 4th-year medical student at AUB in 1983, and I was on campus that Sunday. I don't remember if I was in the midst of my ER clinical rotation or some other rotation that month. My father had died in that very ER a few weeks prior, on September 12. He had collapsed to the floor at home. I had carried him onto an ambulance, 
and we had taken our last ride together to the hospital, across the Green Line dividing the capital into two warring factions. He had recovered consciousness during that ride, long enough to whisper to me his last words: "I cannot move my legs." Fifteen minutes after arriving to the ER, he had a cardiac arrest and died from a presumed dissecting thoracic aortic aneurysm. His medical student son could not save him. But on that Sunday, October 23, still grieving the loss of my dad, I came face-to-face with a human tragedy that I was not yet equipped to handle. It was an apocalyptic scene, straight out of 19th-century war massacres. Bearing witness to what was happening, I was stunned and found myself briefly, like my dad, but for a different reason, unable to move. The surgical chief resident was doing his best to orchestrate the triage of the casualties. He dispatched me to one of the injured Marines lying down on the pavement.

I had not yet visited the US, nor come face-to-face with its legendary military. Like many young Lebanese with big dreams, I knew "America" through the biased lens of its exported movies, its rock bands, and the handful of brave US college professors who taught us at AUB in wartime. English being my third language after Arabic and French, I actually had a hard time understanding the American slang of my professors during my first freshman semester. Regardless, my ambition was to train as a neurosurgeon in the US, if it would have me. The profile on my application would have read, "Middle Eastern, war-torn country, no Ivy League school credentials" - not exactly check marks that propelled me to the top of any US neurosurgical training priority list.

I approached this wounded Marine, whose life I was suddenly put in charge of, with enormous trepidation. $\mathrm{He}$ was shirtless, an impressive amalgam of muscle, grit, and composure. He was riddled with rocks and shrapnel, and I was riddled with fear. He deserved a real doctor, and all he got was me. I simply could not let him die. I kneeled next to him, visibly shaken. He was conscious and bleeding actively from his left temple, and probably from other places I could not see. Yet he was incredibly serene. I glanced for advice at my overburdened chief resident, who was working feverishly a few bodies away. He gestured to me to put pressure on the wound. I did, with my ungloved and probably hesitant hand, and held tight. That's all I did, out there in the middle of the street; that's all I knew to do while waiting for a free spot for him inside. Perhaps it was the way I looked or my tremor; perhaps he sensed my recent loss, my sadness, my incompetence. But this man, injured from head to toe, oozing blood, honor, and duty, this man who left his family behind and risked his life to bring peace to a people he never knew, this foreigner in a strange land, who was hated and targeted by others in my own country, just turned slightly to look at me, broke a smile and said, "Don't worry, doc, you will be fine." The patient was comforting the physician, the injured soothing the healthy, the victim forgiving the could-be executioner, the foreigner guiding the native. It was ironic, embarrassing, and uplifting all at once.

But one more thing struck me that day. This fallen hero I had just met in the flesh did not look like the mythical figures depicted and glorified in the American movies
I had seen. The lone rangers and cowboys, warriors and crime fighters, leading men and comedians, physicians and scientists that I wanted to emulate as a teenager, that were chosen by American directors and producers to represent American culture, looked more like me: sunlight reflected readily off their skin. In other words, they were White. But on October 23, 1983, my most impactful life lesson that eclipsed in an instant many of the pointless and mindless heroes of my childhood was unintentionally but indelibly stamped on me through my brief encounter with the first authentic American patriot I ever came across. His skin happened to be blessed with enough pigment to help it absorb, rather than reflect, most of the sunlight that shines on it. Yet on that day, some of that Beirut sunlight bounced off my wounded Marine as he lay bleeding on Lebanese soil, struck me back, and showed me who he was. That light carried with it a lot of the heart and soul of an American Marine, his courage and resilience, his intelligence and sensibility, generosity and wisdom, grace under fire and dignity under strife. But additionally, perhaps there were lessons of determination in spite of discrimination, survival through rebellion, lessons carried and amplified across generations of oppression and slavery. On that October day, the unforgettable teacher who gave this impressionable young Lebanese man the shortest yet longest-lasting lesson of his life, the best possible ambassador who could have represented the essence and destiny of the US to the rest of the world, was a courageous and dignified American citizen, an American Marine, a Black American Marine ... and thank God he was.

I was stunned by his surreal words and could not utter a reply. A lot of the thoughts I had about the encounter percolated in my head over the rest of the day, well after we had parted ways. Perhaps I had convinced myself that my silence might help mask the rest of my medical and psychological incompetence or that it dignified better the sanctity of the white coat that I did not yet deserve to wear. Perhaps I too might appear calm and instill hope in this valiant man, that he might survive his ordeal. Regardless, it was easier to stay quiet in the midst of the deafening sounds of death and moaning that surrounded us. With my hand firmly held on his temple for several minutes, I silently kept looking at the face of authenticity. More than ever, I wanted to breathe the air from the land that generates men and women of his caliber. He was eventually whisked away to be admitted and probably undergo surgery. The rest of this horrific day remains a blur in my memory. With all the chaos, I never found out his name, whether he lived or died.

\section{Minneapolis, May 25, 2020}

On May 25, 2020, another Black American, with turmoil all around him, was also lying down on a street, not by choice either, but under very different circumstances. His country was not at war, at least not in the traditional sense. George Floyd was forced to lie down in shame on his belly, under the Minneapolis sun, whose rays his skin mostly absorbed. Uninjured by the shrapnel of foreign hatred, he was still victim of an oppressive knee, the symbol of a more evil weapon than suicide bombing: chronic insidious domestic racism. The man kneeling was White 
like me, but this is where the similarity ends. He kneeled on him, not next to him. He was not a student, his uniform was not a white coat, and he presumably represented law and order. His intentions were not to heal but to punish severely. The flow he was stopping was the vital air in George's trachea, not the gushing blood from a Marine's temple. His knee was neither trembling nor hesitant; it is a curse of humanity that injustice seems invariably more swift and determined than the slow wheels of its nemesis, justice. That White officer was fueled at least by gross incompetence, superior arrogance, abusive power, and indifference to the predicament of a fellow man; and at worst, by open hatred toward all men and women of a different race. The plea of "I can't breathe" rang empty and uninspiring to a police officer deafened by prejudice. His knee did not let go until life was whisked away. But the nation heard George, the nation was outraged, and the nation was inspired.

Did George Floyd ever stand a chance on the ground that day? I don't know. My mind fantasizes and imagines an alternate universe where George mutters to the policeman, "Don't worry, officer, you will be fine." Maybe he would have so surprised and stunned his executioner with these words that he would have disarmed him from his prejudice, and maybe, just maybe, that knee would have weakened a little and eased its grip on his throat, bringing the momentum of violence to an end. Utopia aside, in our reality, George's death appropriately shocked us all, including those good men and women in uniform who serve and protect with their lives each and every community, often paying the ultimate price in the line of duty. Our nation, at its best, a beacon of hope to the rest of the world, simply cannot continue to marginalize, mistreat, vilify, or murder Black men and women. Tragically, healthcare disparities, educational inequities, and socioeconomic differences already disadvantage and decimate them along with other minorities, yet the greater crime is the collective sin of omission perpetrated in the mind of those who remain indifferent, oblivious, or worse, those who secretly cheer.

George Floyd's death has triggered nationwide protests against racism and police brutality. It has inspired symbolic kneeling, widespread denunciations, and position statements by individuals and institutions. In times like these, words are certainly better than silence, and actions are better than words. But an even better response than that would be for our so-called leaders to rise to the occasion, inspire a desire, and empower an ability to identify, educate, and reform young American minds well before prejudicial thoughts ever manifest in their brains.

\section{Miami, June 6, 2020}

This country that became my new home opened its doors to me 30 years ago, ironically, first through Minneapolis, where I did my residency in neurosurgery. But it is Miami, with its national, ethnic, racial, and religious diversity, that I have called home for 25 years. In all the years that have passed, I have never forgotten those most meaningful and formative minutes from that encounter in October 1983. I have told this story many times to family and friends. I have never finished it without having goose bumps. The words of that Marine sometimes echo fleet- ingly in my mind during surgery, in conversation with patients, or quite often when I meet veterans who like to reminisce about their service to their country.

As fate would have it, serendipity smiled twice at me this past year and reunited me with two survivors of the blast of 1983. I was traveling on a domestic flight and chatting with a man sitting next to me. On account of my accent, he asked me where I was from. He knew Beirut and had been there. Not only was he there, but he was one of the Marines who miraculously survived the blast, uninjured. He had been dispatched earlier that morning to a shed behind the main building to fetch some equipment. Of all the seats on all the planes flying over all fifty states on all the days of the year, he had to sit beside me. His timing was impeccable. And my second stroke of luck came this past January, as I was visiting Lebanon and having dinner with a childhood friend and her husband, Pierre Sabbagh. We reminisced about the war days, and I happened to recount my Marine story to them for the first time just to discover with amazement that Pierre, who was a professional photographer in the 1980s, had spent the night on the Marine compound and had left it minutes prior to the blast that morning. Upon hearing the deafening explosion, he quickly turned back and, as the first professional photographer on the premises, snapped numerous photographs documenting the apocalyptic scene. In all the time I had known him, little did I know of his key role in this event or that his photographs had been celebrated over the years in many media outlets. ${ }^{1}$ I asked him to share with me any photos he had of any African American Marines being rescued. He found one and only one, of a man dazed and covered with white dust, being carried away on a stretcher. I looked closely at the picture and the man's left temple appeared swollen.

\section{Epilogue}

I don't know what became of my inspiring Marine. What was his name? Did he survive? Is he healthy and successful? Is he retired in Florida? How many lives did he touch so powerfully after mine? Or is he ill? Is he a patient in the Veterans Affairs system? Did the US healthcare institutions fail him because of the color of his skin and in spite of the content of his character? Did he survive a horrific blast and a crumbling building that nearly crushed him 4 decades ago while on foreign soil only to falter under the rubble of racial prejudice here at home? I pray not. I need him to have beaten the odds; I need him to be chanting with Maya Angelou that still he rises, like the air that we breathe. I want to meet him again to tell him and show him what impact he had on the life of somebody he undoubtedly does not remember. I want to let him know that, for his incredible resolve, courage, stamina, and heroism, he is and always will be in a league of his own. He needs to know how chance encounters with the right people at the right time often leave deep imprints that mold irreversibly. I need to thank him for making me fall in love with his land and his people. I need to show him how, because of him, I knew that the US was indeed the right place for me. Because of him, I learned to value much more that quiet stoicism that patients show me daily; I learned that kindness is free to give and yet paid 
back manyfold in return; I learned that patients do not choose their illnesses, that all patients deserve our time and our empathy; and I learned that those special patients who carry their burden with inspiring dignity and courage deserve our deepest respect and admiration. I want to tell him that every neurosurgeon has a story like mine. We all have a moment in time when we chose a path or at least were drawn in a certain direction because of an encounter, a tragedy, a triumph, a smile, or even an encouraging word. Because of the privilege given to us, as neurosurgeons, we owe our patients, our communities, and our country a lot in return. But what I really want to tell him most of all is that because of him and many like him, I carry today enormous hope in my heart that even after 4 decades have passed, many Americans still harbor the same values that he possesses, not the least of which are decency of character and nobility of purpose. Because of them, we stand a chance of rising above the social turmoil that is tearing us apart.

After this initial reunion, my Marine and I will then take a stroll together and, as he fed my soul in 1983, I will feed his soul today by reading to him some of the writings of the Lebanese-American philosopher Gibran Khalil Gibran. I will stop at one special quote, strikingly appropriate for these tumultuous times. Standing together under
American sunlight, one of us reflecting it and the other one absorbing it, we will shout in unison, one loud voice, to all who care to listen:

Do not be merciful, but be just, for mercy is bestowed upon the guilty criminal, while justice is all that an innocent man requires.

\section{References}

1. Soussi A. 1983 Beirut barracks bombing, through the lens of a camera. Al Jazeera. October 23, 2018. Accessed July 23, 2020. https://www.aljazeera.com/indepth/features/1983beirut-barracks-bombing-lens-camera-181022055902870. html

\section{Disclosures}

Dr. Morcos is a consultant for Leica Microsurgical and has direct stock ownership in Kogent.

\section{Correspondence}

Jacques J. Morcos: jmorcos@med.miami.edu.

INCLUDE WHEN CITING

Published online August 7, 2020; DOI: 10.3171/2020.7.JNS202686.

CAANS 2020, except where prohibited by US copyright law 